\title{
Quran, name, and scientific communication
}

\author{
Ajat Sudrajat \\ History Education Department, Universitas Negeri Yogyakarta, Indonesia \\ Email:ajat@uny.ac.id
}

Ita Rahmania Kusumawati

Universitas Hasyim Asy'ari, Indonesia

Email: itajombang111@gmail.com

\begin{abstract}
The objective of this study is to investigate the views of the Quran about the origin of the name and its position in relation to language and the development of science. The research model is literature research utilizing the sources collection (heuristic), source criticism, interpretation, and writing. The findings of this study are: (1) the Quran states that Allah SWT gives teachings about the names to the Prophet of Adam As; (2) These names correlate with the language because they are composed of the names that have been introduced to the Prophet Adam As; (3) The name and language are two sides of money; (4) Names, languages, and concepts can further be the main capital that humans have to develop scientific communication.
\end{abstract}

Keywords: Quran, Name and Language, Scientific Communication. 


\section{INTRODUCTION}

William Shakespeare's (2017) well-known phrase states: "What's in a name? That which we call a rose by any other name would be as sweet". It means "What is the meaning of a name? If you give another name to a rose, it will still smell fragrant". When we read at a glance, the expression seems to give the impression of unnecessary or denying the important meaning of a name. However, if listened to and pondered more deeply, it tells the importance of a name.

Is a name important? Each name usually contains the expectations of the name giver or maker. The hopes in it signal good wishes in accordance with the name. Therefore, the name should have a good meaning to motivate and be the pride of its owner. A name is also very closely related to the identity of something. A certain identity both in the form of visible and invisible objects is attached to the name. Thus, name and giving a name to something is the beginning of knowledge.

The importance of a name, especially in the perspective of the Quran or Islam, can be seen from the first verse of a series of five verses that came down to the Prophet Muhammad SAW in Al-Alaq: "Read with (mention) the name of your Lord Who Created". Furthermore, the letters in the Quran begin with mentioning the name of God. Also, the use of the names of God called 'al-asma al-husna' functions as a companion and reinforcer of prayer or supplication to God. Similarly, in the hadith related to a newborn person ('aqiqah), the next step after being redeemed by slaughtering a goat and cutting its hair is to give a name to the baby (Quthb, 2003).

In addition to mentioning the name of God, in the fifth verse of Al'alaq, Allah SWT states "He teaches man what he does not know". What man does not know deals with the name of something. Therefore, it is important to trace the origin of names or a name attached to an object or 'something'. Who firstly gave the name or where did the name come from; what about the potential that human beings have in relation to the ability to give names; and what about the development that is a further consequence of the existence of these names? Are between name and language two sides piece of money? by saying a name, there is a sound which is an articulation of the name. What is the relationship between the existence of these names with the diversity of languages possessed by mankind and the functions attached to them, and also with the development of science. 


\section{METHODS}

This study seeks to explore the concepts of name, language, and scientific communication in the Quran. Overall, this study is concerned with a thought. Therefore, the model used in this study is library research. The model used is strengthened by critical historical methods through the stages of source collection, source criticism, interpretation, and writing.

\section{RESULTS AND DISCUSSION}

\section{Origin of the Name}

In the Islamic perspective, with reference to the Quran, the emergence of names can not be separated from the grace of God Almighty in the form of potential given to human beings. The Quran has revealed that Allah SWT is the Supreme Creator, and among all His creations are the so-called human beings. The Quran explains that man was created from the elements of the earth, then after the perfection of his creation, the Divine Spirit was inserted into the man (QS Shad (38): 71-72).

Based on the above verse, man is a creation that consists of two basic elements that cannot be separated from each other, namely the elements of the earth and the Divine Spirit. Therefore, it cannot be called human if the two do not become integral units. Such a situation can be analogized as that of water which is a mixture, to a certain extent, between the elements oxygen and hydrogen. Thus, when oxygen and hydrogen levels are separated, it will no longer be water. At the same time, Allah SWT has given a number of potentials to this human being.

With regard to the potential of human beings, we can refer to the explanations of Quraish Shihab when he elaborated the contents of verses 30 39 of the Al-Baqarah. According to him, before the event or creation of Prophet Adam As, Allah had planned for human beings to bear the responsibility of the caliphate on this earth. Therefore, for these purposes and objectives, human beings are endowed with a number of potentials. One of the potentials is to know the names of objects or 'things' and the function of the objects or 'things' that have been named. Thus, at the same time, when Allah introduced to Prophet Adam As the names of objects or things, there is directly a language attached to those names. Therefore, the name and the language can be likened to a piece of money (Shihab' 1996). 


\section{Names and Languages}

As stated above, name and language are two sides of money. When one name is mentioned, there has been articulation or pronunciation with words over an object or something else to which it is intended. Giving this name is the initial treatment of Allah SWT to Prophet Adam As. After the process of creation was done to the Prophet Adam As as caliph, the first lesson given by Allah SWT is to teach the names. The teaching of these names is listed in Surah Al-Baqarah (2) verse 31, which means:

"He taught Adam the names of all things; then He presented the things to the angels and said: "Tell Me the names of those if what you say is true?" "Glory to You," they replied, "we have no knowledge except what You have taught us: in fact You are the One who is perfect in knowledge and wisdom."

Tafsir Jalalain states that the names taught to the Prophet Adam As are the names of objects as a whole by inserting into his heart the knowledge of the object names. The objects in question are not only dead objects, but also living objects or intelligent beings. The ability to mention the names of these objects at once as God's way of showing the superiority that Adam As had over the Angels (Al-Mahalli \& As-Suyuthi, 1985)

The teaching of these names, at the same time, is a way for Allah SWT to convince the Angels of their doubts about the creation of Adam As as caliph. A certain ability is not possessed by the Angels but it is given by Allah SWT to Prophet Adam As. Furthermore, to prove the ability of Adam As as a caliph, Allah SWT asked Adam As to tell the names of the objects to the Angels.

In relation to the above verse, in Tafsir Al-Mishbah, Quraish Shihab states that Allah SWT has taught the names of all objects to the Prophet of Adam As. According to him, Allah SWT has given Adam As the potential to know the names of whole objects or words used to refer to these objects. Also, He taught him to simultaneously know the function of those objects "(Shihab, 2006). This view is similar to what Marcuse stated that the naming of an object not only indicates its function, but also the function that has been shown, as well as a limitation of the meaning of the object and does not allow the existence of other functions and meanings. (Russell, 2001).

In general, based on sunnatullah that a person will not know what it is, unless there is a name. By saying something about an object, it means that someone has given a name (symbol) to it, so that it can distinguish it from other 
objects. Furthermore, after obtaining a name for an object, it can then classify and place it in a meaningful context. Thus, a name is a symbol of the object that bears that name.

\section{How to Teach Names}

There are different interpretations among the scholars about how Allah SWT did when teaching the names of the objects to the Prophet of Adams As. Some scholars understand the teaching of names to Adam As in the sense of teaching words. They argue that Adam As was shown the objects, and at the same time, Adam As heard a voice calling the names of the objects displayed. Others argue that Allah SWT inspired Adam As the names of the objects when they were displayed so that he has the ability to give names to each object and can distinguish them from each other.

According to Quraish Shihab, this second opinion is better than the first. According to him, this thing has been included in the word "teaching" because teaching is not always in the form of dictating or conveying a word or idea, but it can be honing the existing potential. Therefore, the potential is honed and gives birth to knowledge. This assertion shows that one of the specialities of the Prophet Adam As is his ability to express what comes to his mind, thus leading him to know. On the other hand, the ability of the Prophet Adam (peace be upon him) to give a name to everything is a step towards the creation of knowledgeable human beings and the birth of science. (Shihab, 2006).

In this context, Allah SWT has proved and shown the superiority of Prophet Adam As in terms of science. Allah taught Prophet Adam As the names of all objects and then He showed them to the Angels while saying: "Tell Me the names of those if what you say is true". It is true that Prophet Adam As and his descendants are more worthy to be the caliph on earth. Giving a name thus is the first step to acquiring knowledge.

There is an invaluable lesson from the above explanation. First, the ability to give names and language is something that is taufiqiyah, which means that Allah is the one who taught it to human beings. Without it, human beings will not be able to speak and know the names of objects. Then, humans develop it through experience. Naming an object is synonymous with identification, categorization, and classification. Second, one of the means to prosper the world is through science. With science, this world will be prosperous and beneficial to human beings. Without science this world will be ruined. Thus, the question 
of the origin of the name, which according to Casssirer \& Nugroho (1990), is often and always questioned in every age, can be answered through the Quran.

\section{The Concept of Language Diversity}

With the introduction of the names of objects to the Angels by the Prophet Adam As, as stated in verse 33 of the Albaqarah: "O Adam, tell them the names". In this case, Adam As has used the medium of language. Thus, in addition to being given the potential to know the name of an object, Adam As and all humans are also endowed with the potential to speak. For example in the Quran Surah Ibrahim (14) verse 4 and Surah Ar-Rum (3) verse 22, it is stated that:

We have not sent any Rasool except that he speaks the language of his own people, so that he could explain to them clearly. Then Allah leaves in error whom He will and guides whom He pleases: He is the Mighty, the Wise. (QS Ibrahim (14): 4).

Another verse of the Quran states that:

And yet others of His signs are the creation of the heavens and the earth, and the difference of your languages and colors; surely there are signs in this for the knowledgeable (QS Ar-Ruum (30): 22).

The word 'illa billisani qaumihi' means 'except with the spoken language (and common sense) of his people. According to Quraish Shibab, language is not only a means of communication but also a reflection of the minds and views of the people who use that language. Language can describe the character and views of the language users. Quraish Shibab quoted Russel that the structure of language describes the metaphysical beliefs as well as the elements of natural phenomena embraced by the nations that use them. For example, the word women in Indonesian means human beings who must be respected and glorified or they must guide and educate (Shihab, 2008).

Furthermore, the word alsinatakum which is a plural form of "spoken" word can also be used in the sense of language and sound. Language differences are clearly seen in community life. Moreover, these language differences are eternal. Such differences are not due to human design but as part of the sunnatullah. (Shihab, 2012).

Among the signs of God's power include the creation of the heavens and the earth, the differences in languages that humans have, some speak Arabic 
and some speak Ajam and various other languages. Meanwhile, Quraish Shihab asserts that among the signs of God's power are differences in languages and dialects possessed by humans. The signs of God's power related to language are differences in existing languages. Some speak Arabic, Tartar, Roman, French, Barbarian, Abyssinian, Hindi, 'Ajam, Armenian, Kurdish, and many more. The whole diversity of languages is taught by no one except God.

Sayyid Quthb in Tafsir fi Zhilalil-Quran volume 9 states that the creation of human beings with various languages and skin colours has a correlation with the creation of the heavens and the earth which is so amazing. The differences in air temperature on the earth's surface and environmental differences due to the nature of the earth's position astronomically have implications for differences in language and skin colour. (Quthb, 2003).

The uniqueness of human beings does not actually lie in their ability to think, but in their ability to speak (White,1949). Cassirer \& Nugroho (1990) called humans as animal simbolycum, creatures that use symbols, which generically has a wider scope than homo sapiens, i.e thinking creatures because in their thinking activities he uses symbols (Collins, 2009). Without having this language ability, humans are unable to pass cultural values from one generation to the next. Without language, humans are no different from animals in general.

Furthermore, in Surah Ibrahim verse 4 above, the word liyubayyina which accompanies the word bilisani qaumihi. Al-bayan means teaching, which is reading the Quran. The reading is intended to facilitate recitation to His servants and to facilitate in articulating the letters from the articulator areas, namely the throat, tongue, and lips based on the variety of articulations and types of letters.

In Tafsir al-Misbah, the word al-bayan initially means clear. The word is understood by Thabathaba'i in the sense of "potential to reveal" meaning the words/speech with which can be revealed what is in the mind. Furthermore, this scholar states that a word does not just create sound by using the chest cavity, vocal cords and oesophagus.

Through the inspiration given by Allah SWT to man, he can understand the meaning of the voice that comes out, with which he can present something from this real-world (Shihab, 2012). The teaching of al-bayan is not limited to speech, but includes all forms of expression including art and facial expressions. According to al-Biqai, the word al-bayan, is the potential of thinking, that is, knowing the issue of kulli and juzi, judging the visible and the supernatural 
which analogizes it with the visible. Once by signs, another time by calculation, the third time by prophecy, and the next time by looking into the universe, as well as other means, while distinguishing which is good and bad (Shihab, 2012).

The word al-bayan contains all the potential to unravel something hidden in the mind as well as explain and teach it to others. Once with words, at other times with deeds, speech, writing, gestures, and so on. Furthermore, it is stated that human beings are given potential by Allah SWT in the form of the ability to speak, reason, speak, and express thoughts (al-bayan). This ability, can only be done by humans. With this ability, human civilization can grow and experience great progress (Shihab, 2012).

\section{Language and Scientific Thinking}

Man can think well because he has a language. Thinking happens by using language or common sense words. These languages or words are used to express or give birth to something that is thought of. Language or words are outward signs (articulated speech or voice or written signs) to express meaning and object. Language can thus be characterized as a series of sounds and at the same time a symbol in which the series of sounds forms a certain meaning (Hurd, 2000).

Through symbols, humans can compile what is known as vocabulary. Through vocabulary that he acquires, humans perform thinking activities and communicate the results of that thought. Therefore, the activity of thinking is another side of the possession of language and a special characteristic of human beings. This characteristic distinguishes humans from other creatures. This causes human beings to be called thinking animals (al-insanu khayawan al-nathiq).

Language encourages humans to think abstractly. Through language, factual objects can be transformed into abstract language symbols. Thus, one can think about an object, even though the object is not factually located in the place where the thinking activity takes place. The existence of these abstract language symbols allows humans to think about things continuously.

Language also gives humans the ability to think orderly and systematically. The transformation of factual objects into abstract symbols embodied in the vocabulary is summed up by grammar as a means of expressing a thought or expression of feeling. Both informative and emotive aspects are reflected in the language used. In other words, when a person speaks, the information conveyed contains emotive elements and vice versa. However, there can be a situation 
where the two elements can be separated, for example, the phone book tends to solely provide information, while in the strings of a song, it includes emotions (White, Cooper, \& Hedges, 2009).

Based on the above description (Iyengar \& Massey, 2019) language has symbolic, emotive, and affective functions in human life. The symbolic function of language is especially seen in scientific communication. Meanwhile, emotive and affective functions are clearly viewed in aesthetic communication. Communication using language will contain this symbolic and emotive element. However, in Kemeny's view, the use of language in scientific communication even has an emotional tendency (Hurd, 2004).

Everything that becomes the object of the language is called a referent. In this case, we take a word or symbol (spoken or written) and use it to denote something (object, quality, or relationship) or to connect other words that become nouns and the like. If a name has been chosen in a language, its use must be permanent so that there is no confusion. Words are combined in sentences, and those sentences also have meaning. Thus, we have language as a means of communication (Keohane, Lane, \& Oppenheimer, 2014).

The name, which is articulated in the form of language, is the most important tool for a philosopher and scientist. Also, it becomes a medium for finding and conveying expression. The 20th century has given increasing attention to the problem of names and language as well as the communication and function of signals and symbols (Sumarlan, Firmansyah, \& Darmawan, 2021). This attention has led to the development of semantics or research on the meaning, function of names and language, as well as the relationship between words and objects, analytical linguistic or philosophical currents and symbolic logic (Mitroff \& Mason, 2012).

The 20th century has led to new attention to grammar and structure. Most people assume that the name or the language is a natural thing, like the air we breathe, that does not need to be thought deeply. But nowadays, many experts, including philosophers and scientists who utilize the method of analytical logic see that the investigation of the meaning, principles and rules of language is a fundamental problem in philosophy. Some philosophers and scientists pay attention to linguistic analysis and theories of language. The words definitions, propositions, hypotheses, axioms, principles of verification and others are increasingly being observed and become the main topic of conversation in philosophical research (Ricoeur, 1976) 
The ability to use language is one of the special qualities of human beings. Animals can only produce a small amount of natural sounds and only show taste or pain. Such a voice or expression may accompany the presence of food, friends, or danger. With the development of consciousness, intelligence, and social groups, and with the creation and use of verb symbols, human beings gain the possibility to have independence and develop knowledge that is not possessed by animals.

The language used for speech, with an appeal to the ear, has the advantage of gestures that have appeal to the eye and sight. Speakers do not need to be seen. All groups in the world have a language used for conversation. But the language does not have permanency (determination) that is objective and easily forgotten. With the loss of the language, the knowledge gained by the group is also lost.

The development of written language is an important step for the growth of civilization. Without written language, there will be no progress. If speech is broken down into its principal elements and symbols are used for those elements as in the alphabet, then a written language will be born and we acquire a relatively permanent means of communication and expression.

The written language will be a storehouse of old knowledge, and the language has the ability to overcome the limitations of place and time, as well as to defend itself against changes that occur in oral transmission. The new method of recording will of course give greater permanence to the spoken language. The development of language has enabled the rapid increase of knowledge and its branch in various specialized fields.

Language also has many functions including cognitive functions. Based on cognitive function, language serves to explain the position that we can test the truth and whether we accept or reject it. This is the knowledge we seek in some sciences and philosophies.

Many of our languages are emotive in some ways; they may be expressive about feelings and situations, or they may be evocative and require an emotional response from others. Language may be imperative, that is, commanding or directing to control the actions of others. Language may also be ceremonial in nature as we use it in respect of others or in conversation and ritual. 


\section{Name as a Scientific Concept}

It has been stated above that name and language are two sides of money. In the same analogy, name and concept are also two sides of money. It can even be 'three in one' If it involves all three, namely name, language, and concept. All three are an inseparable unity. As described above, human beings are capable of constructing concepts, creating, developing, and presenting ideas, and implementing them (Shihab, 1996).

The word "concept" derives from the Latin word concipere, which means to include, contain, take, suck, and catch. The word concipere comes from the noun conceptus which means catch, then the word concept comes. Thus, the concept actually means "catch". Capturing something can be realized by making a concept. The result of the catch is called the concept. In addition to the word concept, the term "idea" comes up. The "idea" is a word derived from the Greek word "eidos". "Eidos" means visible, which is an appearance, shape, image, or form that can be seen. Thus, concepts and ideas have the same meaning (Wheeler, 2021).

An idea or concept substantively means an intellectual action used to capture something. Capturing in this sense is not the same as seeing with the naked eye or hearing with the ears, nor it is the same as imagining. Capturing is an intellectual act. This capturing action is called simple appraisal, which is essentially a process used to achieve a concept or idea. Thus the concept or idea is the result of the process. (Rohmana, 2015).

When the concept or idea is expressed in one word or more, it becomes a "term". Logically, there is a difference between terms and words. The term can include several words or a number of words despite embodying a logical unit of capture, such as the Supreme Deity, unity in diversity, and just and civilized humanity.

In its development, a term, as an activity of knowing, in modern phenomenology always bears the characteristic of intentionality. A capture is always an activity of capturing towards something else namely something that on spontaneous consciousness does not depend on the activity of capturing. As the catches are abstract, he reveals objects incompletely. But, he reveals a certain clear content (Nasr et.al, 2015)

There are two other things that need to be considered in relation to the concept, namely comprehension and existence. A definite and precise understanding of the comprehension and existence of concepts is absolutely 
essential in uttering because concepts or ideas are constitutive elements in thought activities. Thinking is made up of decisions, and decisions are made up of concepts or ideas or terms.

Comprehension is the whole meaning covered in a concept or term. The whole in this context is a unity of complex meanings contained in a concept. If you want to make it explicit, many words are often used. To use simple language; comprehension is content or what is contained in a concept. If what is stated is the basic things, it is called basic comprehension, while if what is stated is a derivative of the basic understanding of a concept, then it is called complementary comprehension.

Every concept or idea also has an environment or territory. The environment or territory of a concept includes all things that can be called a concept. The poorer the comprehension is, the wider the existence will be. On the contrary, the richer the comprehension is, the narrower the existence will be. For example, the concept of animals, if there is no information that accompanies the concept, people will not know its further specifications. Then, it can be said that the concept is poor in comprehensiveness which means having a wide area of application. From the concept of 'animal' above, any type of animal can be included. Conversely, if the concept has a rich understanding, such as 'animals that can fly', then the area of existence will be narrower, namely only point to animals that can fly (Ikhwan, 2010).

The concept can thus be understood as a general description of an idea or the idea of a reasoning system. The general picture is usually abstract. In a system of reasoning, one must provide a boundary or scope in order to clearly distinguish something from another, whether in the form, nature or material of the idea. For example, the "table" will be clearer with a concept, so it will also be different from the "chair" because of the previous concept. The concept of a table is different from the concept of a chair (Nurtawab, 2020)

In this case, a definition is understood first. The concept also contains efforts to classify and categorize. For example, in the concept of a table or chair, we must see and know all the forms of tables, then all the tables (which have been seen or observed) must go into the group of tables without exception. Similarly, poultry (which have been seen or observed), all types of birds must be included in the group of poultry.

If you look at a table, for example, the table is circular or round, having four or three legs. What you see is a manifestation of the concept of "table". 
That is one of the "table concept", which is a table with three legs and a round surface. A table, as observed, cannot yet be used to formulate a decision on what is meant by the "table concept". Because the measure is the definition of the table concept, it should also be understood that the concept explains the substance of something.

The "concept of the table" formulated in the realm of the mind is an entity that should not go out of its essence (because it is bordered). The essence of the "table concept" is the presence of legs and the top part. It can be at least one leg and a maximum of four or more. Similarly, the top part can be round or square. This will make it easier for everyone to understand a table with all its attributes. Based on some of these examples, it can be stated that the name (in this case for example a table and chair) is a concept that needs a definition to measure its entity.

\section{CONCLUSIONS}

The Quran states that Allah SWT is the Essence who gave teachings about names to the Prophet Adam As. These names certainly can not be separated from and with language, because it is the articulation and construction of the names that have been introduced to the Prophet Adam As. Also, name and language are two sides of money. Names, languages, and concepts can be called three in one which can further be the main capital that humans possess to develop science.

\section{REFERENCES}

Al-Mahalli, J. \& As-Suyuthi, J. (1985). Tafsir al-Jalalain. Dar Ibn Katsir.

Cassirer, E., \& Nugroho, A. A. (1990). Manusia dan kebudayaan: Sebuah esai tentang manusia. Gramedia.

Collins, P. (2009). Philosophy and Humanism. Philosophia, 37(2).

Hurd, J. M. (2000). The transformation of scientific communication: A model for 2020. Journal of the American society for information science, 51(14), 1279 . 1283.

Hurd, J. M. (2004). Scientific communication: new roles and new players. Science G Technology Libraries, 25(1-2), 5-22.

Ikhwan, M. (2010). Western studies of the Quranic narrative: from the 
historical orientation into the literary analysis. Al-Jami'ah: Journal of Islamic Studies, 48(2), 387-411.

Iyengar, S., \& Massey, D. S. (2019). Scientific communication in a post-truth society. Proceedings of the National Academy of Sciences, 116(16), 7656-7661.

Keohane, R. O., Lane, M., \& Oppenheimer, M. (2014). The ethics of scientific communication under uncertainty. Politics, Philosophy $\mathcal{E}$ Economics, 13(4), 343-368.

Mitroff, I. I., \& Mason, R. O. (2012). Creating a dialectical social science: Concepts, methods, and models (Vol. 25). Springer Science \& Business Media.

Nasr, S. H., Dagli, C. K., Dakake, M. M., Lumbard, J. E., \& Rustom, M. (2015). The Study Quran. A new translation and commentary, 19.

Nurtawab, E. (2020). Quranic readings and Malay translations in 18th-century Banten Qurans A. 51 and W. 277. Indonesia and the Malay World, 48(141), 169-189.

Quthb, S. (2003). Tafsir fi Zhilalil Quran. Jilid 9. Penerjemah: As'ad Yasin dkk. TIM GIP.

Ricoeur, P. (1976). Interpretation theory: Discourse and the surplus of meaning. TCU press.

Rohmana, J. A. (2015). Metrical verse as a rule of Quranic translation: Some reflections on RAA Wiranatakoesoema's soerat Al-Baqarah (18881965). Al-Jami'ah Journal of Islamic Studies, 53(2), 439-467.

Russell, B. (2001). The problems of philosophy. OUP Oxford.

Sastrapratedja, M. (1982). Manusia multi dimensional: Sebuah Renungan Filsafat. PT. Gramedia.

Shakespeare, W. (2017). Romeo and Juliet, Act II, Scene II. The Oxford Shakespeare (1914 edition).

Shihab, M. Q. (2008). Tafsir Al-Misbah: Pesan, kesan, dan keserasian alquran, Jilid 7. Lentera Hati.

Shihab, M. Q. (2012). Tafsir Al-Misbah: Pesan, kesan, dan keserasian alquran, Jilid 10. Lentera Hati.

Shihab, M. Q. (2012). Tafsir Al-Misbah: Pesan, kesan, dan keserasian alquran, Jilid 13. Lentera Hati.

Shihab, M. Q. (1996). Wawasan Al-Quran: Tafsir tematik atas pelbagai persoalan umat. Mizan Pustaka. 
Quran, name, and scientific communication (Ajat Sudrajat, Ita Rahmania Kusumawati)

Shihab, M. Q. (2006). Tafsir Al-Misbah: Pesan, kesan, dan keserasian alquran, Jilid 1. Lentera Hati.

Sumarlan, I., Firmansyah, R., \& Darmawan, H. (2021). Alquran communication patterns and efforts to build positive communication. Journal of Social Studies (JSS), 17(2), 255-270.

Wheeler, B. (2021). Quran as scripture in classical Muslim scholarship. Religions, 12(11), 1013.

White, H. D., Cooper, H., \& Hedges, L. V. (2009). Scientific communication and literature retrieval. The handbook of research synthesis and metaanalysis, 2, 51-71.

White, L. A. (1949). The science of culture, a study of man and civilization. 
Informasi, Vol. 51. No. 2. (2021), 365-380 